OPEN ACCESS

Edited by:

Sebastian Leuzinger, Auckland University of Technology,

New Zealand

Reviewed by: Christian Koerner, University of Basel,

Switzerland

Iván Prieto,

Spanish National Research Council,

Spain

Rodica Pena, University of Göttingen,

Germany

*Correspondence:

Göran I. Ågren

goran.agren@s/u.se

Specialty section:

This article was submitted to

Functional Plant Ecology,

a section of the journal

Frontiers in Plant Science

Received: 18 July 2019 Accepted: 10 January 2020

Published: 07 February 2020

Citation:

Ågren Gl and Weih M (2020) Multi-Dimensional Plant Element Stoichiometry - Looking Beyond Carbon, Nitrogen, and Phosphorus.

Front. Plant Sci. 11:23.

doi: $10.3389 /$ fpls.2020.00023

\section{Multi-Dimensional Plant Element Stoichiometry-Looking Beyond Carbon, Nitrogen, and Phosphorus}

\author{
Göran I. Ågren ${ }^{1 *}$ and Martin Weih ${ }^{2}$ \\ ${ }^{1}$ Department of Ecology, Swedish University of Agricultural Sciences, Uppsala, Sweden, 2 Department of Crop Production \\ Ecology, Swedish University of Agricultural Sciences, Uppsala, Sweden
}

Nutrient elements are important for plant growth. Element stoichiometry considers the balance between different nutrients and how this balance is affected by the environment. So far, focus of plant stoichiometry has mainly been on the three elements carbon (C), nitrogen $(\mathrm{N})$, and phosphorus $(\mathrm{P})$, but many additional elements are essential for proper plant growth. Our overall aim is to test the scaling relations of various additional elements ( $\mathrm{K}, \mathrm{Ca}, \mathrm{Mg}, \mathrm{S}, \mathrm{Cu}, \mathrm{Zn}, \mathrm{Fe}, \mathrm{Mn})$, by using ten data sets from a range of plant functional types and environmental conditions. To simultaneously handle more than one element, we define a stoichiometric niche volume as the volume of an abstract multidimensional shape in $n$ dimensions, with the $n$ sides of this shape defined by the plant properties in question, here their element concentrations. Thus, a stoichiometric niche volume is here defined as the product of element concentrations. The volumes of $\mathrm{N}$ and $\mathrm{P}\left(V_{N P}\right)$ are used as the basis, and we investigate how the volume of other elements $\left(V_{O t h}\right)$ scales with respect to $V_{N P_{3}}$ with the intention to explore if the concentrations of other elements increase faster (scaling exponent $>1$ ) or slower $(<1)$ than the concentrations of $\mathrm{N}$ and $\mathrm{P}$. For example, scaling exponents $>1$ suggest that favorable conditions for plant growth, i.e., environments rich in $\mathrm{N}$ and $\mathrm{P}$, may require proportionally higher uptake of other essential elements than poor conditions. We show that the scaling exponent is rather insensitive to environmental conditions or species and ranges from -3.804 to 1.976 (average 0.384 ) in nine out of ten data sets. For single elements, Mg has the smallest scaling exponent (0.524) and $\mathrm{Mn}$ the largest (2.666). In two of the ten data sets the scaling exponent is negative but positive in the other eight sets. Comparison between laboratory determined stoichiometric relations and field observations suggest that element uptake in field conditions often exceeds the minimal physiological requirements. The results provide evidence for the view that the scaling relations previously reported for $\mathrm{N}$ and $\mathrm{P}$ can be extended to other elements; and that $\mathrm{N}$ and $\mathrm{P}$ are the driving elements in plant stoichiometric relations. The stoichiometric niche volumes defined here could be used to predict plant performances in different environments.

Keywords: ecological stoichiometry, elementome, ionome, homeostasis, mineral nutrients, plant growth, scaling, stoichiometric niche volume 


\section{INTRODUCTION}

At least 16 to 17 elements are considered essential for proper plant growth (Mengel and Kirkby, 2001; Watanabe et al., 2007). Most interest has been devoted to carbon $(\mathrm{C})$, nitrogen $(\mathrm{N})$, and phosphorus $(\mathrm{P})$ as these elements are among the quantitatively most important, and $\mathrm{N}$ and $\mathrm{P}$ are in general expected to be limiting plant growth (Elser et al., 2007). Plant element stoichiometry considers how the balance of plant-internal elements is influenced by the abiotic and biotic environment. For example, Knecht and Göransson (2004) and Ladanai et al. (2010) showed that there are strong correlations between concentrations of elements in foliage. However, such correlations require that elements scale isometrically (change in constant proportions) although several studies have shown that $\mathrm{N}$ and $\mathrm{P}$ scale approximately as $N \propto P^{1.37}$ or $P \propto N^{0.73}$ (Niklas et al., 2005; Niklas, 2006; Niklas and Cobb, 2006; Kerkhoff and Enquist, 2006). We are not aware that similar relations have been studied with other elements, although for proper plant functioning it could be expected that all essential elements should increase in proportion to each other (homeostasis), but deviations from proportionality would indicate that some elements may rapidly become critical in a changing environment. The overall aim of this paper is thus to test the scaling relations of various elements, by using available data sets from a broad range of plant functional types and environments. We hypothesize that scaling relations similar to the one between $\mathrm{N}$ and $\mathrm{P}$ can be extended to other elements ( $\mathrm{K}$, $\mathrm{Ca}, \mathrm{Mg}, \mathrm{S}, \mathrm{Cu}, \mathrm{Zn}, \mathrm{Fe}, \mathrm{Mn}$ ) (H1); the full suite of micronutrients is rarely reported and our analyses will be restricted to these eight. Although elements other than $\mathrm{N}$ and $\mathrm{P}$ can be limiting and changes in climate and $\mathrm{N}$ deposition may alter which elements may replace $\mathrm{N}$ or $\mathrm{P}$ as limiting, the stoichiometric relations beyond $\mathrm{C}, \mathrm{N}$ and $\mathrm{P}$ have received little attention. In a recent paper, Tian et al. (2018) reviewed shifts in stoichiometric relations in experiments with nutrient additions, elevated $\mathrm{CO}_{2}$ and temperature. They found that $\mathrm{N}$ additions increased $\mathrm{N}$ relative to other elements but experimental warming tended to decrease $\mathrm{N}$ and $\mathrm{P}$, and responses to elevated $\mathrm{CO}_{2}$ varied with element; $\mathrm{N}: \mathrm{Mg}$ and P:Mg increased and $\mathrm{N}: \mathrm{Mn}$ and P:Mn decreased. The analyses of stoichiometric couplings are generally done by looking at shifts in element ratios. This is no problem as long as the analysis is restricted to $\mathrm{C}, \mathrm{N}$, and $\mathrm{P}$, where there are only three unique ratios. However, this approach becomes unwieldy when many elements are involved; with 16 elements there are 120 possible ratios. We will, therefore, look for an alternative metric that can be used to summarize many elements. The metric we want to use should be applicable to an arbitrary number of elements and its value should be increasing with increasing element concentrations. Our second basic hypothesis ( $\mathrm{H} 2$ ) is that $\mathrm{N}$ and $\mathrm{P}$ are the driving elements in plant stoichiometric relations and other elements will scale with respect to them. We will suggest a metric called stoichiometric niche volume based on the multidimensional niche concept by Hutchinson (1957). González et al. (2017) and Penuelas et al.
(2019) suggest stoichiometric niches as important tools for investigating nutritional relations. Baxter (2015) argues also for metrics that summarize the whole suite of elements (the ionome or elementome). Blonder (2018) reviews the use of the hypervolume niche concept, which we here extend and apply to plant nutrients.

\section{MATERIALS AND METHODS}

\section{Theory}

The growth response of plants with respect to the internal concentration of growth limiting nutrients $\left(c_{n}\right)$ can be described such that below a certain internal concentration $\left(c_{n, \min }\right)$ plants do not grow at all, then up to some higher concentration $\left(c_{n, o p t}\right)$ plant relative growth rate increases linearly, and above that declines to 0 at some maximal concentration $\left(c_{n, \max }\right)$ (Ågren and Weih, 2012), Figure 1. We will call the distance $c_{n, \max }-c_{n, \min }$ the fundamental niche of the species, i.e. the range over which the plant can exist, and the range $c_{n, \min }-c_{n, o p t}$ the response niche, i.e. the range over which plant growth responds to changes in nutrient availability; $c_{n}-c_{n, \text { min }}$ defines the realized niche, although we will use only $c_{n}$ as $c_{n, \min }$ is rarely known and is also expected to be small. To simultaneously handle more than one element we defined stoichiometric niche volumes as the volume of a parallelepiped (i.e., an abstract multidimensional shape) in $n$ dimensions, with the $n$ sides defined by the $n$ element concentrations in question.

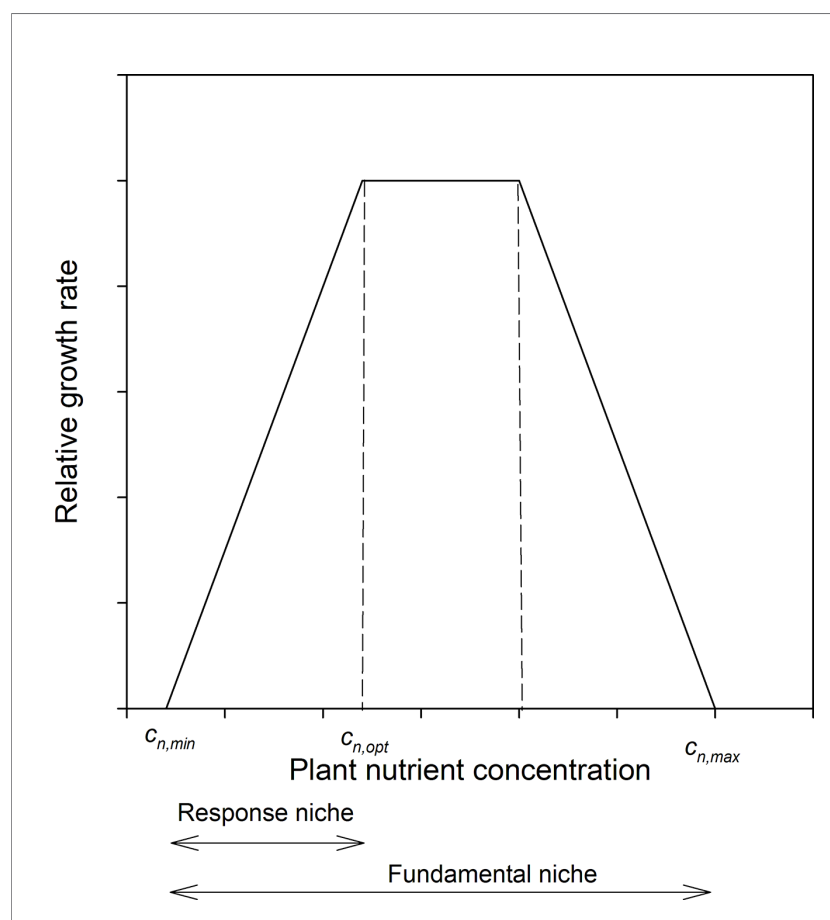

FIGURE 1 | Schematic diagram of the relation between relative growth rate and plant tissue concentration of the limiting element. Scales are arbitrary. 
In particular, we used the following two stoichiometric volumes $(V)$ based on the realized niches; the first is defined by the product of the plant $\mathrm{N}$ and $\mathrm{P}$ concentrations

$$
V_{N P}=c_{N} c_{P}
$$

and the other by the product $(\Pi)$ of the concentrations of the other elements

$$
V_{\text {Oth }}=\prod_{n \neq N, P} c_{n}
$$

We interpret these volumes as the n-dimensional stoichiometric space a plant occupies. $\mathrm{N}$ and $\mathrm{P}$ are considered important for ecosystem functioning because both nutrients commonly limit production of plant biomass (Vitousek and Howarth, 1991). Therefore, we chose the product of $\mathrm{N}$ and $\mathrm{P}$ rather than some other combination to see how other elements behave relative to these two elements, and it was then logical to combine all elements in the same manner.

We then calculated the scaling relations between these two volumes. With scaling we understand the following relationship between the two sub-volumes defined above

$$
V_{\text {Oth }}=\beta V_{N P}^{\alpha}
$$

Using log-transformed values

$$
\ln \left(V_{O t h}\right)=\ln \beta+\alpha \ln \left(V_{N P}\right)
$$

$\alpha$ is the scaling exponent, in which we are interested in, leaving the intercept of the relation, $\beta$, for future studies as its interpretation goes well beyond the scope of this study (see Niklas and Hammond, 2019 for an in-depth discussion of $\beta$ ). Regressions were calculated as reduced major axes (RMA) (Niklas, 2006) as is conventional in this type of studies. A scaling exponent of 1 indicates that the two volumes increase proportionally, whereas a value $<1$ means that the concentrations of the other elements increase more slowly than those of $\mathrm{N}$ and $\mathrm{P}$.

To test the importance of elements to be included in Oth, we calculated $\alpha$ for the average of 10 random combinations of 2-8 elements in our data sets (Ideal not included) and investigated how the number of elements included affected $\alpha$.

\section{Data Sets}

A summary of the data sets used to test the scaling relations with information on elements included is given in Table 1. Most results will be based on $\mathrm{N}$ and $\mathrm{P}$ versus $\mathrm{K}, \mathrm{Ca}, \mathrm{Mg}$ (macronutrients), as $\mathrm{S}$ and micronutrients are not reported in all studies; $\mathrm{C}$ is also excluded as it is rarely reported. Some of the data sets (Tomato, Birch, Wheat1, Salix, $\mathrm{CO}_{2}$-exp, and Hawaii) were split into subsets to investigate possible effects of treatments or other external factors.

Tomato: We used data from Ingestad et al. (1994a). These data were obtained in laboratory experiments with tomato plants (Lycopersicon esculentum Mill. cv. Solentos) grown under strict nitrogen limitation and at several daily quantum flux rates, of which we used two subsets $\left(6\right.$ and $18 \mathrm{~mol} \mathrm{~m}^{-2} \mathrm{~d}^{-1}$ ) to view the effects of light on the scaling relation. The experiments were

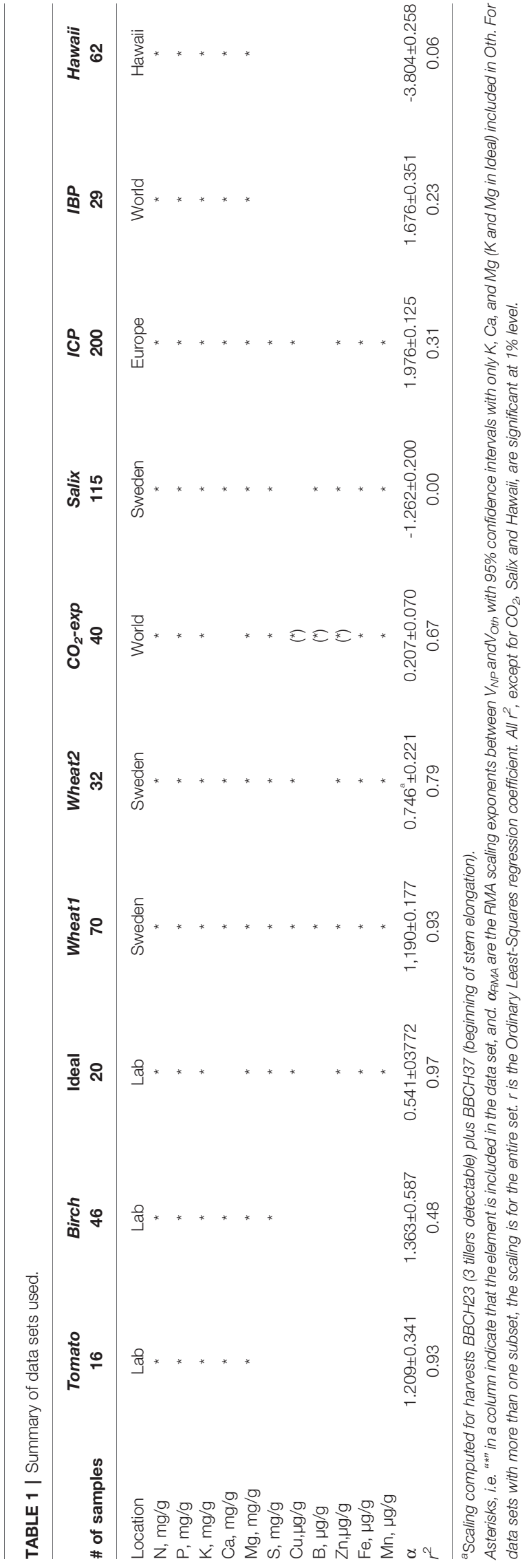


conducted with the technique of controlled addition rate of the limiting nutrient (Ingestad and Lund, 1979; Ingestad and Lund, 1986). Scalings are from data for plants at different growth rates and sampling dates. Nutrient concentrations are tissue concentrations for whole plants. This data set should illustrate effects of light intensity on stoichiometry.

Birch: We used data from laboratory experiments with birch plants (Betula pendula Roth.) grown under strict nutrient limitation and at various light intensities. The experiments were conducted with the technique of controlled addition rate of the limiting nutrient (Ingestad and Lund, 1979; Ingestad and Lund, 1986). N-limited data are from Ingestad et al. (1994b); P-limited data are from Ericsson and Ingestad (1988); K-limited data are from Ericsson and Kähr (1993); Mglimited data are from Ericsson and Kähr (1995); Mn-limited data are from Göransson (1994); S-limited data are from Ericsson and M. Kähr (pers. comm.); Fe-limited data are from Göransson (1993); Zn-limited data are from Göransson (1999); and Cu-limited data are from Göransson (1998). Nutrient concentrations are tissue concentration for whole plants. These experiments were performed similarly to those with N-limited tomato but with other elements limiting. Scalings are from different relative addition rates and sampling dates. This data set should illustrate the effects of different limiting nutrients on stoichiometry.

Ideal: This is not a directly measured data set. Instead we created it from the Tomato data in Fig. 1 in Ågren and Weih (2012) by calculating the nutrient concentrations corresponding to relative growth rates of $5 \%, 10 \%, \ldots, 100 \%$ of maximum relative growth rates. In this way we got concentrations at equal relative growth rates for all elements [ideal nutrient proportions sensu Ågren (1988)]. These concentrations are such that a decrease in any of them leads to a decrease in the relative growth rate; all elements are equally limiting. This data set should illustrate the minimum relative stoichiometric requirements.

Wheat 1: Data are from a fertilization experiment with winter wheat (Triticum aestivum L.) grown at seven sites in central and southern Sweden and with four levels of $\mathrm{N}$ fertilization (Hamner et al., 2017). Data are for aboveground plant parts. Scalings were calculated separately for three subsets representing different stages of development according to the $\mathrm{BBCH}$ scale $(\mathrm{BBCH} 23$ 3 tillers detectable, $\mathrm{BBCH} 37$ flag leaf visible, and $\mathrm{BBCH} 65$ full flowering; Lancashire et al., 1991).

Wheat2: Data are for winter wheat grown in Sweden (Weih et al., 2016). Data are for aboveground plant parts (vegetative parts and grain). Scaling is over replicates and different preceding crops, and includes data from three stages of development: Vegetative plant parts at beginning of stem elongation (BBCH31) and beginning of flowering (BBCH61), and only reproductive parts (kernels at crop maturity). This data set should illustrate effects of plant developmental stage and choice of plant parts on stoichiometry.

$\mathbf{C O}_{2}$-exp: Data are from a series of experiments with elevated $\mathrm{CO}_{2}$ concentration. A summary of the experiments is given in
TABLE 2 | Summary of $\mathrm{CO}_{2}$ experiments analyzed.

\begin{tabular}{|c|c|c|c|}
\hline Reference & Location & Species & $\begin{array}{l}\text { Treatments, } \\
\mu \mathrm{mol} \mathrm{mol}\end{array}$ \\
\hline Luomala et al. (2005) & OTC ${ }^{a}$, Finland & Pinus sylvestris L. & $362 \& 693$ \\
\hline $\begin{array}{l}\text { Blank and Derner } \\
(2004)\end{array}$ & Glasshouse & Lepidium latifolium L. & $360 \& 699$ \\
\hline Johnson et al. (2004) & $\begin{array}{l}\text { FACE, } \\
\text { Tennessee }\end{array}$ & $\begin{array}{l}\text { Liquidambar } \\
\text { styraciflua (L.) }\end{array}$ & Ambient \& 542 \\
\hline Le Thiec et al. (1995) & $\begin{array}{l}\text { Open top, } \\
\text { France }\end{array}$ & $\begin{array}{l}\text { Picea abies (L.) } \\
\text { Karst. }\end{array}$ & Ambient \& A+350 \\
\hline $\begin{array}{l}\text { Oksanen et al. } \\
(2005)\end{array}$ & OTC $^{a}$, Finland & Betula pundula L. & Ambient \& $2^{\star} A$ \\
\hline $\begin{array}{l}\text { Roberntz and Linder } \\
\text { (1999) }\end{array}$ & $\begin{array}{l}\text { Branch bags, } \\
\text { Sweden }\end{array}$ & $\begin{array}{l}\text { Picea abies (L.) } \\
\text { Karst. }\end{array}$ & $360 \& A+337$ \\
\hline $\begin{array}{l}\text { Pfirrmann et al. } \\
\text { (1996) \#5502 }\end{array}$ & Phytotron & $\begin{array}{l}\text { Picea abies (L.) } \\
\text { Karst. }\end{array}$ & Ambient \& A+300 \\
\hline Walker et al. (2000) & OTC $^{a}$, California & Pinus taeda L. & $354,525,700$ \\
\hline Weight et al. (2011) & Greenhouse & $\begin{array}{l}\text { Picea abies (L.) } \\
\text { Karst. }\end{array}$ & $400 \& 700$ \\
\hline
\end{tabular}

${ }^{a}$ OTC, open top chamber.

Treatments refer to the $\mathrm{CO}_{2}$ levels used in the treatment. Treatment ambient (A) means that no level was reported for the untreated system.

Table 2. When experiments included combinations of $\mathrm{CO}_{2}$ and other treatments, only ambient (A) and pure elevated (E) $\mathrm{CO}_{2}$ treatments were used in our analyses. Elevated refers to all $\mathrm{CO}_{2}$ levels above ambient. Data are for foliage. This data set should illustrate the effects of $\mathrm{CO}_{2}$ on stoichiometry.

Salix: Data are from Ågren and Weih (2012) from a fertilization experiment (two subsets: unfertilized control, C, and fertilized and irrigated, $\mathrm{W}+\mathrm{F}$ ) with six willow (Salix spp.) genotypes. The fertilizer was combined with irrigation and included $\mathrm{N}, \mathrm{P}, \mathrm{K}, \mathrm{Ca}, \mathrm{Mg}, \mathrm{S}, \mathrm{Fe}, \mathrm{Mn}, \mathrm{B}, \mathrm{Zn}, \mathrm{Cu}$, and $\mathrm{Mo}$ in the first year, but only $\mathrm{N}, \mathrm{P}$, and $\mathrm{K}$ in the second year, which was the year in which the material for this analysis was sampled. Scalings are from mature leaves of the different genotypes and crown positions. This data set should illustrate consequences of fertilization for stoichiometry.

ICP: Data are based from ICP Forests foliage data (http://icpforests.net), sampled over Western Europe. Data are for foliage of Abies alba, Fagus sylvatica, Larix decidua, Picea abies, Pinus nigra, Pinus pinaster, Pinus sylvestris, Pseudotsuga menziesii, Quercus pubescens, and Quercus robur. Scalings are over all species and locations. This data set should illustrate effects of species and growth location on stoichiometry.

IBP: Data are from the International Biological Program (IBP) investigations (Cole and Rapp, 1981) for foliage from 17 different forests grown at nine sites worldwide. This data set should illustrate large-scale geographical effects and covers differences in both species and soils. Scaling is over all species and all locations. Data are for foliage.

Hawaii: Data are from a study of changes in foliar nutrients along a long-term soil development (300 to 4,100,000 years, 7 subsets) mesic series in Hawaiian rain forests (Vitousek et al., 1995). Scaling exponents are calculated from data for nine different species except for the oldest site where data was available for only eight species. This data set should illustrate 

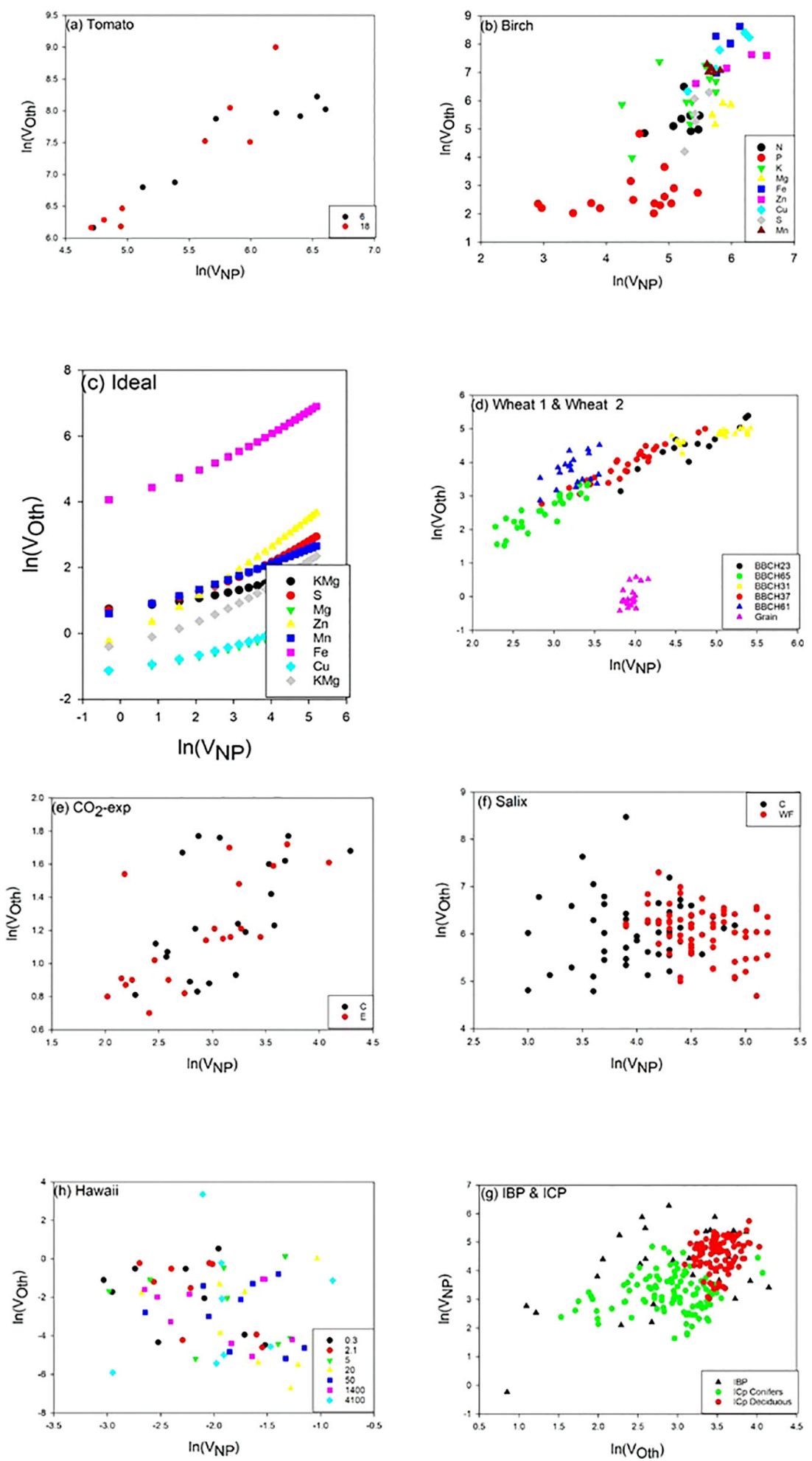

FIGURE 2 | Scatter plots of $\ln \left(V_{O t h}\right)$ versus $\ln \left(V_{N P}\right)$ for the ten different data sets. For tomato, the different symbols show the two different light levels. For birch, the different symbols show different limiting elements. For Wheat1 \& Wheat2, circles are from Wheat1 and triangles from Wheat2 and different colors show different development stages. For Salix and $\mathrm{CO}_{2}$, the different symbols show the two different treatments. For IBP \& ICP, the different symbols show the two different data sets. For Hawaii, the different symbols show the different site ages (ky). Scales can be different between panels. In panel d: BBCH23 3 tillers detectable, BBCH31 beginning of stem elongation, $\mathrm{BBCH} 37$ flag leaf visible, $\mathrm{BBCH} 61$ beginning of flowering. 
effects of long-term soil development on stoichiometry. Data are for foliage.

\section{RESULTS}

Results from the extremely well-controlled birch experiments show that response niches for $\mathrm{N}$ and $\mathrm{P}$ almost fill the corresponding fundamental niches whereas the response niches for the other elements are considerably smaller than for the fundamental niches (Table 3). The volume of the response niche for NP is as much as $73 \%$ of the fundamental niche while for the other elements, where we have data, it is only $0.02 \%$.

We note that taken over all data sets the scaling between $\mathrm{N}$ and $\mathrm{P}$ is $P \propto N^{0.21 \pm 0.05}$ (Supplementary Material, Figure S1), which is similar to what has been found in the studies cited in the introduction $(H 1)$.

Scatter plots of the relations $\ln \left(V_{\text {Oth }}\right)$ versus $\ln \left(V_{N P}\right)$, where Oth includes $\mathrm{K}, \mathrm{Ca}$, and $\mathrm{Mg}$ as these elements are included in all data sets, are shown in Figure 2, and the scaling exponents $\alpha$ are given in Table 1. The scaling exponents are close, ranging from 0.938 (Wheat1) to 2.479 (Hawaii) in spite of the large differences in origins of the data sets. In the data sets, where the data can be split into subsets depending on treatments or other factors, the variations between subsets are small (Table 4). The scaling exponents for different limiting elements in the Birch data set are shown in Figure 3, indicating very small effects of the actually limiting nutrient. The scaling exponents for different site ages in the Hawaii data set are shown in Figure 4, suggesting a weak increase in the scaling exponent with site age. The Ideal data set deviates from the other ones by having a much smaller scaling exponent (0.155) which also shows up when looking at the scaling element by element versus NP; except for S and Fe the scaling exponents are much smaller than found in the other data sets. One reason is that the relation between $V_{N P}$ and $V_{\text {Oth }}$ in Ideal is convex whereas it is concave in the other data sets (Figure 2).

As Table 5 shows, element identity matters as different elements scale differentially, but even more important is how many elements are included in Oth. Figure 5 shows that the scaling exponent increases linearly with number of elements $(n)$ $\left(\alpha=-0.7687+0.8044 n, r^{2}=0.8449\right)$.

TABLE 3 | Sizes of fundamental niches and response niches for birch.

\begin{tabular}{lccc}
\hline Element & Fundamental niche & Response niche & Response/fundamental \\
\hline $\mathrm{N}, \mathrm{mg} / \mathrm{g}$ & 42.3 & 41.8 & 0.99 \\
$\mathrm{P} \mathrm{mg/g}$ & 5.7 & 4.2 & 0.74 \\
$\mathrm{~K}, \mathrm{mg} / \mathrm{g}$ & 40.2 & 5.4 & 0.13 \\
$\mathrm{~S}, \mathrm{mg} / \mathrm{g}$ & 2.7 & 1.7 & 0.64 \\
$\mathrm{Mg}, \mathrm{mg} / \mathrm{g}$ & 3.5 & 1.2 & 0.34 \\
$\mathrm{Zn}, \mu \mathrm{g} / \mathrm{g}$ & 46.8 & 25.7 & 0.55 \\
$\mathrm{Mn}, \mu \mathrm{g} / \mathrm{g}$ & 213.8 & 13.1 & 0.06 \\
$\mathrm{Fe}, \mu \mathrm{g} / \mathrm{g}$ & 207.1 & 40.0 & 0.19 \\
$V_{N P}$ & 241 & 175 & \\
$V_{\text {Oth }}$ & 787211653 & 150816 & \\
$V_{\text {Oth }} V_{N P}$ & 3264948 & 861 &
\end{tabular}

TABLE 4 | RMA scaling exponents $\left(\alpha_{R M A}\right)$ with 95\% confidence intervals for regressions between $\operatorname{In}\left(V_{N P}\right)$ and $\operatorname{In}(V O t h)$ for data sets that can be split into subsets. For Wheat2 All refers to $\mathrm{BBCH} 23$ plus $\mathrm{BBCH} 37$. All ${ }^{2}$, except for $\mathrm{CO}_{2}$ and Salix, are significant at $1 \%$ level.

\begin{tabular}{llccc}
\hline Data set & Treatment & $\mathbf{n}$ & $\boldsymbol{\alpha}_{\boldsymbol{R M A}}$ & $\boldsymbol{r}^{\mathbf{2}}$ \\
\hline Tomato & All & 16 & $1.136 \pm 0.075$ & 0.93 \\
& 6 & 8 & $1.133 \pm 0.269$ & 0.97 \\
Wheat1 & 18 & 8 & $1.138 \pm 0.117$ & 0.97 \\
& All & 70 & $0.984 \pm 0.082$ & 0.93 \\
& $\mathrm{BBCH} 23^{\mathrm{a}}$ & 14 & $0.980 \pm 0.132$ & 0.87 \\
Wheat 2 & $\mathrm{BBCH} 37^{\circ}$ & 28 & $1.005 \pm 0.093$ & 0.92 \\
& $\mathrm{BBCH} 65^{\circ}$ & 28 & $0.949 \pm 0.194$ & 0.82 \\
& All & 39 & $1.025 \pm 0.080$ & 0.50 \\
Salix & $\mathrm{BBCH} 31^{\mathrm{b}}$ & 20 & $0.964 \pm 0.165$ & 0.57 \\
& $\mathrm{BBCH} 61^{\mathrm{d}}$ & 19 & $1.154 \pm 0.110$ & 0.53 \\
& $\mathrm{All}$ & 115 & $1.382 \pm 0.025$ & 0.00 \\
CO $_{2}$-exp & $\mathrm{C}$ & 48 & $1.144 \pm 0.088$ & 0.05 \\
& W & 67 & $1.148 \pm 0.022$ & 0.07 \\
& All & 40 & $1.150 \pm 0.024$ & 0.02 \\
& $\mathrm{~A}$ & 20 & $1.170 \pm 0.060$ & 0.02 \\
& $\mathrm{E}$ & 20 & $1.127 \pm 0.038$ & 0.12
\end{tabular}

${ }^{a} \mathrm{BBCH} 233$ tillers detectable.

${ }^{b} \mathrm{BBCH} 31$ beginning of stem elongation.

${ }^{\mathrm{C}} \mathrm{BBCH} 37$ flag leaf visible.

${ }^{d} \mathrm{BBCH} 61$ beginning of flowering.

${ }^{e} \mathrm{BBCH} 65$ full flowering.

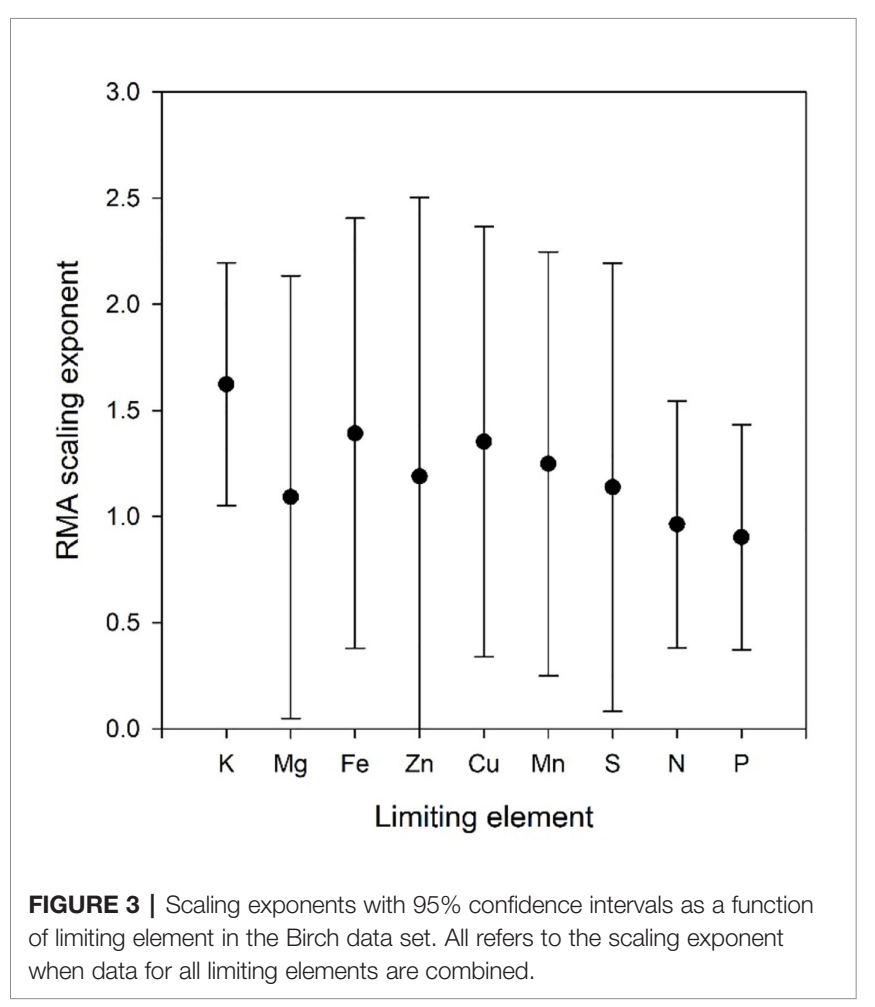

\section{DISCUSSION}

Our general result is that the proposed scaling with NP as a basis is robust as shown by the insensitivity to diverse conditions (limiting element, light intensity, $\mathrm{CO}_{2}$ level, growth location, 


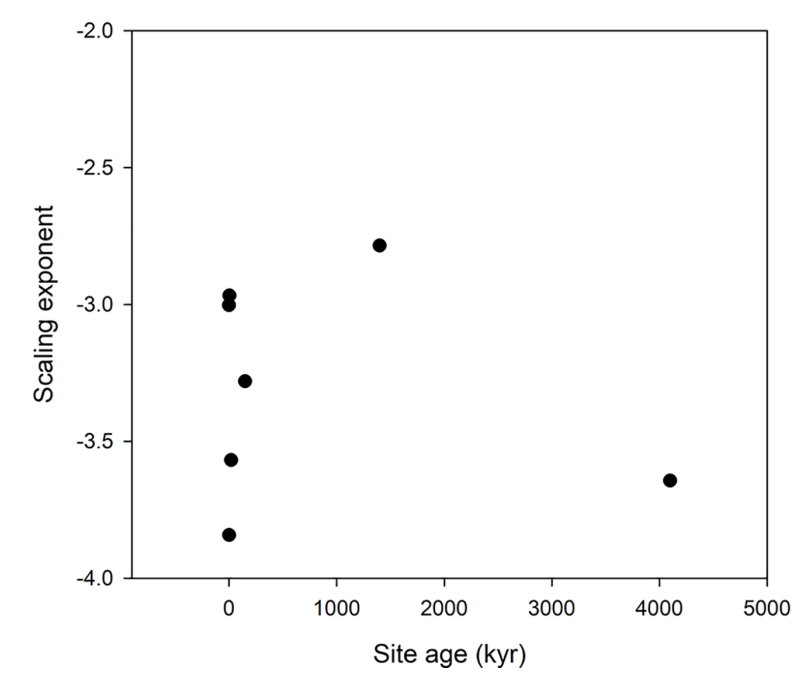

FIGURE 4 | Scaling exponents as function of site age in the Hawaii data set. The lowest age is the value for the scaling taken over all ages.

species) supporting our hypothesis 1 (H1) that scaling relations can be established also for other elements than $\mathrm{N}$ and $\mathrm{P}$ and the predictions proposed by Niklas et al. (2005); Niklas (2006); Niklas and Cobb (2006), and Kerkhoff and Enquist (2006). The only factor that appears to disrupt the scaling is the choice of plant parts (kernels differ from vegetative parts in the Wheat 2 data set, Figure 2), and heavy fertilization not including all elements as in the Salix data set. We no longer observe a trend with site age in the Hawaii data set.We have no explanation for the negative scaling exponent in this data set. On the other hand, the negative scaling exponent in the Salix data set is a result of dilution of some micronutrients caused by increased growth by heavy NP fertilization.

The way we have defined the scaling means that the scaling exponent for several elements should be the sum of the scaling exponents for the individual elements. The choice of elements to include in Oth is, therefore, important as some elements (Mg, S) make a very small contribution compared to others (Fe, Mn), but on average (from Table 3) adding an element should increase the scaling exponent with 0.703 in agreement with Figure 5. As soon as two or more elements are included in Oth, the scaling exponent can, therefore, be expected to be larger than 1 meaning that the combined concentrations of elements in Oth will increase faster than the concentrations of NP. We do not know the physiological reason for this. The faster increase in $\mathrm{P}$

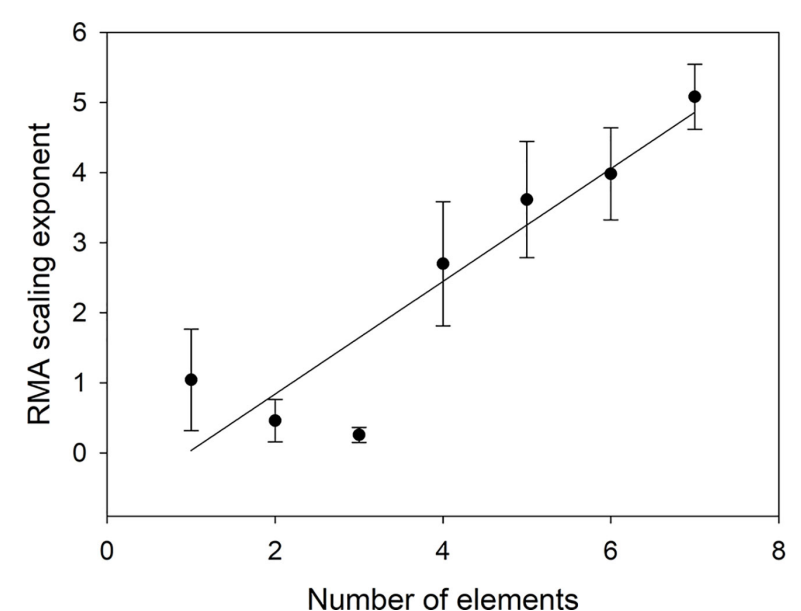

FIGURE 5 | Scaling exponent as a function of the number of elements included in $V_{\text {Oth }}$. The scaling exponent for $n=1$ is the average of the scaling exponents in Table 4.

than $\mathrm{N}$ can be explained by the growth rate hypothesis (e.g. Ågren, 2004), but we do not know if a similar mechanism is applicable also to other elements. It should also be noted that if we can find a mechanistic explanation for the relative changes in plant nutrient concentrations, it does not need to be of the form given by eq (3), because this equation is flexible enough to fit several underlying models. Without an underlying mechanism for the scaling, it is not meaningful to attempt to investigate in detail the intercept $(\beta)$ in the scaling, although this parameter should give further insight into the relations (Niklas and Hammond, 2019). It should also be observed that the choice of units of concentrations ( $\mathrm{mg} \mathrm{g}^{-1}, \mu \mathrm{g} \mathrm{g}^{-1}, \mathrm{~mol} \mathrm{~g}^{-1}$ ) will not affect the scaling exponent as changes of units only shifts data parallel to the axes and thus is important only when analyzing the intercept but not the slope.

The results support our second hypothesis $(\mathrm{H} 2)$ that $\mathrm{N}$ and $\mathrm{P}$ are the driving elements in plant stoichiometric relations and other elements will scale with respect to them. Our choice of the NP niche volume as the basis for the scaling can seem arbitrary, but we think that $\mathrm{N}$ and $\mathrm{P}$ differ from the other elements because they are the most commonly limiting growth. This is reflected by the fact that plants respond over the entire $\mathrm{N}$ and $\mathrm{P}$ fundamental niches (Table 3), whereas plants can take up large quantities of other elements without any positive or negative effects on growth (the response niches are much smaller than the fundamental niches). This should also explain the variability around the

TABLE 5 | RMA scaling exponents $\left(\alpha_{R M A}\right)$ with 95\% confidence intervals for regressions between In $\left(V_{N P}\right)$ and one single elements calculated from the combined Wheat1, Wheat2, plus ICP data and the Ideal data sets respectively. Note that Ca is missing in the Ideal data set.

\begin{tabular}{|c|c|c|c|c|c|c|c|c|}
\hline Element & Mg & $\mathbf{S}$ & $\mathrm{Cu}$ & $\mathrm{Ca}$ & $\mathbf{K}$ & $\mathrm{Zn}$ & $\mathrm{Fe}$ & Mn \\
\hline Combined & $0.524 \pm 0.120$ & $0.477 \pm 0115$ & $0.927 \pm 0.118$ & 1.030 & $0.698 \pm 0.101$ & $0.611 \pm 0.127$ & $1.400 \pm 0.094$ & $2.666 \pm 0.122$ \\
\hline Ideal & $0.297 \pm 0.480$ & $0.449 \pm 0306$ & $0.307 \pm 0.473$ & 0.110 & $0.2487 \pm 0.259$ & $0.742 \pm 0.349$ & $0.582 \pm 0.157$ & $0.394 \pm 0.287$ \\
\hline
\end{tabular}


scaling relation, some of the element uptake has little functional consequences. An associated question is what controls the uptake of elements. $\mathrm{N}$ and $\mathrm{P}$ are probably taken up to the extent that they are available, but uptake of other elements could either be controlled by availability or by plant physiological and/or biochemical requirements resulting in the maintenance of certain nutrient balances (homoestasis). The larger fundamental niches than response niches for other elements than $\mathrm{N}$ and $\mathrm{P}$ will cause the concentrations of these other elements to be higher than physiologically necessary compared to $\mathrm{N}$ and $\mathrm{P}$, resulting in larger scaling exponents than what physiological constraints require. However, the fact that scaling exponents from field data are larger than those in the Ideal data set suggests that plants do not minimize their efforts to acquire nutrients, instead increasing availability of $\mathrm{N}$ and $\mathrm{P}$ provides the plants with resources to take up proportionally more of other elements; scaling exponents larger than 1 in most of the data sets would otherwise indicate faster increasing requirements for other elements than $\mathrm{N}$ and $\mathrm{P}$. We have not included $\mathrm{C}$ in our analyses because $\mathrm{C}$ has not been reported in most of the studies we have used. This might not be a major problem as Ladanai et al. (2010) point out, $\mathrm{N}$ might be a better base for analyzing stoichiometric relations than C.

Ågren and Weih (2012) analyzed causes for variability in stoichiometry in the Salix data set and found that elements could be divided into three groups. The first group (N, P, S, and Mn) was associated with nucleic acids and proteins, the second group $(\mathrm{Mg}, \mathrm{K}$, and $\mathrm{Ca})$ was associated with structure and photosynthesis, and the third group ( $\mathrm{Fe}, \mathrm{Zn}, \mathrm{B}$, and $\mathrm{Al}$ ) with enzymes. These three groups are also apparent with some differences in our scaling relations (Table 3); here Mn appears in the third group and $\mathrm{Mg}$ in the first group. However, Agren and Weih (2012) argue that other principles for classification group the elements differently. The possibility of grouping elements together could simplify the analyses of scaling relations as a smaller number of scaling relations would be necessary to investigate.

In conclusion, it might not be necessary to analyses all bioelements as the niche volume of $\mathrm{N}$ and $\mathrm{P}$ together can predict the niche volume of the other elements. This is also in line with the nutrient balance concept of Baxter (2015), where he argues that combinations of elements (rather than individual elements) should be treated as the phenotypes of interest; and

\section{REFERENCES}

Ågren, G. I., and Weih, M. (2012). Plant stoichiometry at different scales: element concentration patterns reflect environment more than genotype. New Phytol. 164, 944-952. doi: 10.1111/j.1469-8137.2012.04114.x

Ågren, G. I. (1988). The ideal nutrient productivities and nutrient proportions. Plant Cell Environ. 111, 613-620. doi: 10.1111/j.1365-3040.1988.tb01803.x

Ågren, G. I. (2004). The C:N:P stoichiometry of autotrophs: theory and observations. Ecol. Lett. 7, 185-191. doi: 10.1111/j.1461-0248.2004.00567.x

Baxter, I. (2015). Should we treat the ionome as a combination of individual elements, or should we be deriving novel combined traits? J. Exp. Bot. 66, 2127-2131. doi: 10.1093/jxb/erv040 where he visualizes the balance of elements as placed on a beam scale, with $\mathrm{N}$ and $\mathrm{P}$ on one side and all the other elements on the other side. The stoichiometric niche volumes developed in our paper could be used to explore the elemental phenotypes suggested by Baxter (2015). However, our results are based on a correlation between $V_{N P}$ and $V_{O t h}$ and if this is the result of an underlying causal relation, the roles of $\mathrm{N}$ and $\mathrm{P}$ versus other elements can be reversed. Further development could be on how to use the niche volume to predict plant performances and also to investigate in depth how environmental factors (temperature, water availability, soil type.) affects scaling. The lack of such data in our data sets prevented such analyses.

\section{DATA AVAILABILITY STATEMENT}

The raw data supporting the conclusions of this manuscript will be made available by the authors, without undue reservation, to any qualified researcher.

\section{AUTHOR CONTRIBUTIONS}

GA designed the study and made the calculations. GA and MW wrote the manuscript.

\section{ACKNOWLEDGMENTS}

The evaluation was based on data that was collected by partners of the official UNECE ICP Forests Network (http://icp-forests. net/contributors). Part of the data was co-financed by the European Commission (Data achieved at 2018-05-08). We thank Bengt Olsson for comments on the manuscript.

\section{SUPPLEMENTARY MATERIAL}

The Supplementary Material for this article can be found online at: https://www.frontiersin.org/articles/10.3389/fpls.2020.00023/ full\#supplementary-material

Blank, R. R., and Derner, J. D. (2004). Effects of $\mathrm{CO}_{2}$ enrichment on plant-soil relationships of Lepidium latifolium. Plant Soil 262, 159-167. doi: 10.1023/B: PLSO.0000037032.43098.5c

Blonder, B. (2018). Hypervolume concepts in niche- and trait-based ecology. Ecography 41, 1441-1455. doi: 10.1111/ecog.03187

Cole, D. W., and Rapp, M. (1981). "Elemental cycling in forest ecosystems," in Dynamic Properties of Forest Ecosystems (International Biological Programme; 23). Ed. D. E. Reichle (Cambridge: Cambridge University Press), 341-409.

Elser, J. J., Bracken, M. E. S., Cleland, E. E., Gruner, D. S., Harpole, W. S., Hillebrand, H., et al. (2007). Global analysis of nitrogen and phosphorus limitation of primary producers in freshwater, marine and terrestrial ecosystems. Ecol. Lett. 10, 1135-1142. doi: 10.1111/j.1461-0248.2007.01113.x 
Ericsson, T., and Ingestad, T. (1988). Nutrition and growth of birch seedlings at varied relative phosphorus addition rates. Physiol. Plantarum 72, 227-235. doi: 10.1111/j.1399-3054.1988.tb05827.x

Ericsson, T., and Kähr, M. (1993). Growth and nutrition of birch seedlings in relation to potassium supply rate. Trees $7,78-85$. doi: 10.1007/BF00225473

Ericsson, T., and Kähr, M. (1995). Growth and nutrition of birch seedlings at varied relative addition rates of magnesium. Tree Physiol. 15, 85-93. doi: 10.1093/treephys/15.2.85

Göransson, A. (1993). Growth and nutrition of small Betula pendula plants at different relative addition rates of iron. Trees 8, 31-38. doi: 10.1007/BF00240979

Göransson, A. (1994). Growth and nutrition of small Betula pendula plants at different relative addition rates of manganese. Tree Physiol. 14, 375-388. doi: 10.1093/treephys/14.4.375

Göransson, A. (1998). Steady-state nutrition and growth responses of Betula pendula to different relative supply rates of copper. Plant Cell Environ. 21, 937944. doi: 10.1046/j.1365-3040.1998.00294.x

Göransson, A. (1999). Growth and nutrition of Betula pendula at different relative supply rates of zinc. Tree Physiol. 19, 111-116. doi: 10.1093/treephys/19.2.111

González, A. L., Dézerald, O., Marquet, P. A., Romero, G. Q., and Srivastava, D. S. (2017). The multidimensional stoichiometric niche. Front. In Ecol. Evol. 5, 110. doi: $10.3389 /$ fevo.2017.00110

Hamner, K., Weih, M., Ericsson, J., and Kirchmann, H. (2017). Influence of nitrogen supply on macro- and micronutrient accumulation during growth of winter wheat. Field Crops Res. 213, 118-129. doi: 10.1016/j.fcr.2017.08.002

Hutchinson, G. E. (1957). Concluding remarks. Cold Spring Harbor Symp. Quant. Biol. 22, 415-427. doi: 10.1101/SQB.1957.022.01.039

Ingestad, T., and Lund, A. B. (1979). Nitrogen stress in birch seedlings. I. Growth technique and growth. Physiol. Plantarum 45, 137-148. doi: 10.1111/j.13993054.1979.tb01678.x

Ingestad, T., and Lund, A. B. (1986). Theory and techniques for steady state mineral nutrition and growth of plants. Scand. J. For. Res. 1, 439-453. doi: $10.1080 / 02827588609382436$

Ingestad, T., Hellgren, O., and Lund Ingestad, A. B. (1994a). Data base for tomato plants at steady state. Methods and performance of tomato plants (Lycopersicon esculentum Mill. $C v$. Solentos) under non-limiting conditions and under limitation by nitrogen and light. Report 74 (Uppsala, Sweden: Department of Ecology and Environmental Research, Swedish University of Agricultural Sciences)

Ingestad, T., Hellgren, O., and Lund Ingestad, A. B. (1994b). Data base for birch plants at steady state. Performance of tomato plants (Betula pendula Roth.) under non-limiting conditions and under limitation by nitrogen and light. Report 75 (Uppsala, Sweden: Department of Ecology and Environmental Research, Swedish University of Agricultural Sciences).

Johnson, D. W., Cheng, W., Joslin, J. D., Norby, R. J., Edwards, NT, and Todd, D. E. Jr. (2004). Effects of elevated $\mathrm{CO}_{2}$ on nutrient cycling in a sweetgum plantation. Biogeochemistry 69, 379-403. doi: 10.1023/B:BIOG.00000 31054.19158.7c

Kerkhoff, A. J., and Enquist, B. J. (2006). Ecosystem allometry: the scaling of nutrient stocks and primary productivity across plant communities. Ecol. Lett. 9, 419-427. doi: 10.1111/j.1461-0248.2006.00888.x

Knecht, M. F., and Göransson, A. (2004). Terrestrial plants require nutrients in similar proportions. Tree Physiol. 24, 447-460. doi: 10.1093/treephys/24.4.447

Ladanai, S., Ågren, G. I., and Olsson, B. A. (2010). Relationships between tree and soil properties in Picea abies and Pinus sylvestris forests in Sweden. Ecosystems 11, 302-316. doi: 10.1007/s10021-010-9319-4

Lancashire, P. D., Bleiholder, H., Van den Boom, T., Langelüddeke, P., Stauss, R., Weber, E., et al. (1991). A uniform decimal code for growth stages of crops and weeds. Ann. Appl. Biol. 119, 561-601. doi: 10.1111/j.1744-7348.1991.tb04895.x

Le Thiec, D., Dixon, M., Loosveldt, P., and Garrec, J. P. (1995). Seasonal and annual variations of phosphorus, calcium, potassium and manganese contents in different cress-sections of Piceo abies (L.) Karst. needles and Quercus rubra L. leaves exposed to elevated $\mathrm{CO}_{2}$. Trees 10, 55-62. doi: 10.1007/BF00192184

Luomala, E. M., Laitinen, K., Sutinen, S., Kellomäki, S., and Vapavouri, E. (2005). Stomatal density, anatomy and nutrient concentrations of Scots pine needles are affected by elevated $\mathrm{CO}_{2}$ and temperature. Plant Cell Environ. 28, 733-749. doi: 10.1111/j.1365-3040.2005.01319.x

Mengel, K., and Kirkby, E. A. (2001). Principles of Plant Nutrition (Dordrecht: Kluwer Academic Publishers). doi: 10.1007/978-94-010-1009-2

Niklas, K. J., and Cobb, E. D. (2006). Biomass partitioning and leaf N, Pstoichiometry: comparisons between tree and herbaceous current-year shoots. Plant Cell Environ. 29, 2030-2042. doi: 10.1111/j.1365-3040.2006.01578.x

Niklas, K. J., and Hammond, S. T. (2019). On the interpretation of the normalization constant in the scaling equation. Front. In Ecol. Evol. 6, 212. doi: $10.3389 /$ fevo.2018.00212

Niklas, K. J., Owens, T., Reich, P. B., and Cobb, E. D. (2005). Nitrogen/phosphorus leaf stoichiometry and the scaling of plant growth. Ecol. Lett. 8, 636-642. doi: 10.1111/j.1461-0248.2005.00759.x

Niklas, K. J. (2006). Plant allometry, leaf nitrogen and phosphorus stoichiometry, and interspecific trends in annual growth rates. Ann. Bot. 97, 155-163. doi: 10.1093/aob/mcj021

Oksanen, E., Riikonen, J., Kaakinen, S., Holopainen, T., and Vapaavuori, E. (2005). Structural characteristics and chemical composition of birch (Betula pendula) leaves are modified by increasing $\mathrm{CO}_{2}$ and ozone. Global Change Biol. 11, 732748. doi: $10.1111 /$ j.1365-2486.2005.00938.x

Penuelas, J., Fernandez-Martiez, M., Ciais, P., Jou, D., Piao, S., Obersteiner, M., et al. (2019). The bioelements, the elementome, and the biogeochemical niche. Ecology 100, e02652. doi: 10.1002/ecy.2652

Pfirrmann, T., Barnes, J. D., Steiner, K., Schramel, P., Buchs, U., Kuchenhofe, H., et al. (1996). Effects of elevated $\mathrm{CO}_{2}, \mathrm{O}_{3}$ and $\mathrm{K}$ deficiency on Norway spruce (Picea abies): nutrient supply, content and leaching. New Phytol. 134, 267-278. doi: 10.1111/j.1469-8137.1996.tb04631.x

Roberntz, P., and Linder, S. (1999). Effects of long-term $\mathrm{CO}_{2}$ enrichment and nutrient availability in Norway spruce. II. Foliar Chem. Trees 14, 17-27. doi: $10.1007 / \mathrm{s} 004680050003$

Tian, D., Reich, P. B., Chen, H. Y. H., Xiang, Y., Luo, Y., Shen, Y., et al. (2018). Global changes alter plant multi-element stoichiometric coupling. New Phytol. 221, 807-817. doi: 10.1111/nph.15428

Vitousek, P. M., and Howarth, R. H. (1991). Nitrogen limitation on land and in the sea: How can it occur? Biogeochemistry 13, 87-115. doi: 10.1007/BF00002772

Vitousek, P. M., Turner, D. R., and Kitayama, K. (1995). Foliar nutrients during long-term soil development in Hawaiian montane rain forest. Ecology 76, 712 720. doi: $10.2307 / 1939338$

Walker, R. F., Johnson, D. W., Geisinger, D. R., and Ball, J. T. (2000). Growth, nutrition, and water relations of ponderosa pine in a field soil as influenced by long-term exposure to elevated atmospheric $\mathrm{CO}_{2}$. For. Ecol. Manage. 137, 111. doi: 10.1016/S0378-1127(99)00308-4

Watanabe, T., Broadley, M. R., Jansen, S., White, P. J., Takada, J., Satake, K., et al. (2007). Evolutionary control of leaf element composition in plants. New Phytol. 174, 516-523. doi: 10.1111/j.1469-8137.2007.02078.x

Weigt, R. B., Raidl, S., Verma, R., Rodenkirchen, H., Göttlein, A., and Agerer, R. (2011). Effects of twice-ambient carbon dioxide and nitrogen amendment on biomass, nutrient contents and carbon costs of Norway spruce seedlings as influenced by mycorrhization with Piloderma croceum and Tomentellopsis submollis. Mycorrhiza 21, 375-391. doi: 10.1007/s00572-010-0343-1

Weih, M., Pourazari, M., and Vico, G. (2016). Nutrient stoichiometry in winter wheat: Element concentration pattern reflects developmental stage and weather. Sci. Rep. 6, 1-9. doi: 10.1038/srep35958

Conflict of Interest: The authors declare that the research was conducted in the absence of any commercial or financial relationships that could be construed as a potential conflict of interest.

Copyright (๑) 2020 Agren and Weih. This is an open-access article distributed under the terms of the Creative Commons Attribution License (CC BY). The use, distribution or reproduction in other forums is permitted, provided the original author(s) and the copyright owner(s) are credited and that the original publication in this journal is cited, in accordance with accepted academic practice. No use, distribution or reproduction is permitted which does not comply with these terms. 